\title{
New Late Jurassic teleost remains from the Agardhfjellet Formation, Spitsbergen, Svalbard
}

\author{
Maayke J. Koevoets ${ }^{1}$, Jørn H. Hurum ${ }^{1,2} \& \varnothing y$ vind Hammer ${ }^{1}$ \\ ${ }^{1}$ Natural History Museum, University of Oslo, PO Box 1172, Blindern, Oslo 0318, Norway \\ ${ }^{2}$ The University Centre in Svalbard, UNIS, Pb 156, 9171 Longyearbyen, Norway \\ E-mail corresponding author (Maayke J. Koevoets): m.j.koevoets@nhm.uio.no
}

\begin{abstract}
The Agardhfjellet Formation (Middle Jurassic to lowermost Cretaceous) of Svalbard (Norwegian Arctic) is well known for its abundant and unique marine reptile fauna, of ichthyosaurs and plesiosaurs. In an attempt to reconstruct the palaeoecology and palaeoenvironment of the Agardhfjellet Formation, a study of the invertebrate fauna, geochemistry and stratigraphy was conducted. During this study numerous small vertebrate fossils were encountered. Only a few reports of Jurassic teleost from the Arctic were known previously, from the Agardhfjellet Formation on Svenskøya, Kong Karls Land, described as Leptolepis nathorsti, and at Lardyfjellet, East Spitsbergen. We describe more teleost material from the Kimmeridgian and Volgian of the Agardhfjellet Formation in central Spitsbergen and assign a new age, Kimmeridgian, to the original material. This new material also provides more information on the palaeoecology of the Jurassic of Svalbard, showing that fish were probably common in the pelagic fauna of central Spitsbergen together with the better known cephalopods, and could have been important elements of the diet of the marine reptiles.
\end{abstract}

Keywords: Teleost, Leptolepidae, Jurassic, Arctic, Spitsbergen

Received 10. July 2017 / Accepted 13. January 2018 / Published online 17. April 2018

\section{Introduction}

The fossil record of small vertebrates from the Middle Jurassic-Upper Cretaceous of the Arctic is scarce. Woodward (1899) was the first to describe isolated cranial and postcranial elements from an early teleost from the Arctic, which he named as Leptolepis nathorsti. The remains were found in Jurassic "bituminous limestone" and "black shale" on Svenskøya and Kong Karls Land, Svalbard. This refers to the Agardhfjellet Formation (Smith et al., 1976), of mostly Bathonian to Volgian (Tithonian) age. In this study, we describe new teleost remains from the Agardhfjellet Formation in Central Spitsbergen. The goal of this study has been to compare and identify the remains and to extend/ improve the age of teleost finds in Central Spitsbergen. The Agardhfjellet Formation is a shallow-marine deposit consisting mainly of organic-rich black to grey shales and siltstones (Dypvik, 1984; Mørk et al., 1999; Dypvik et al., 2002; Koevoets et al., 2016) with subordinate carbonates and sandstones. The uppermost member, the Slottsmøya Member, is well known for its numerous plesiosaur and ichthyosaur remains (Druckenmiller et al., 2012; Hurum et al., 2012; Knutsen et al., 2012b; Roberts et al., 2014; Delsett et al., 2015).

Our study is largely based on drillcore samples collected in the framework of the $\mathrm{CO}_{2}$ Svalbard project (Sand et al., 2014) (Fig. 1). The primary aim of the project is to document high-resolution biostratigraphy, facies development and sequence stratigraphy in order to evaluate the feasibility of the Agardhfjellet Formation as a suitable seal for $\mathrm{CO}_{2}$ storage in the vicinity of Longyearbyen (Braathen et al., 2012). Six wells were drilled within a $50 \mathrm{~m}$ radius in Adventdalen $5 \mathrm{~km}$ southeast of Longyearbyen, and two wells were drilled $2 \mathrm{~km}$ northwest of Longyearbyen (Braathen et al., 2012). Four of the wells have completely

Koevoets, M.J., Hurum, H.H. \& Hammer, Ø. 2018: New Late Jurassic teleost remains from the Agardhfjellet Formation, Spitsbergen, Svalbard. Norwegian Journal of Geology 98, 289-299. https://dx.doi.org/10.17850/njg98-2-01. 

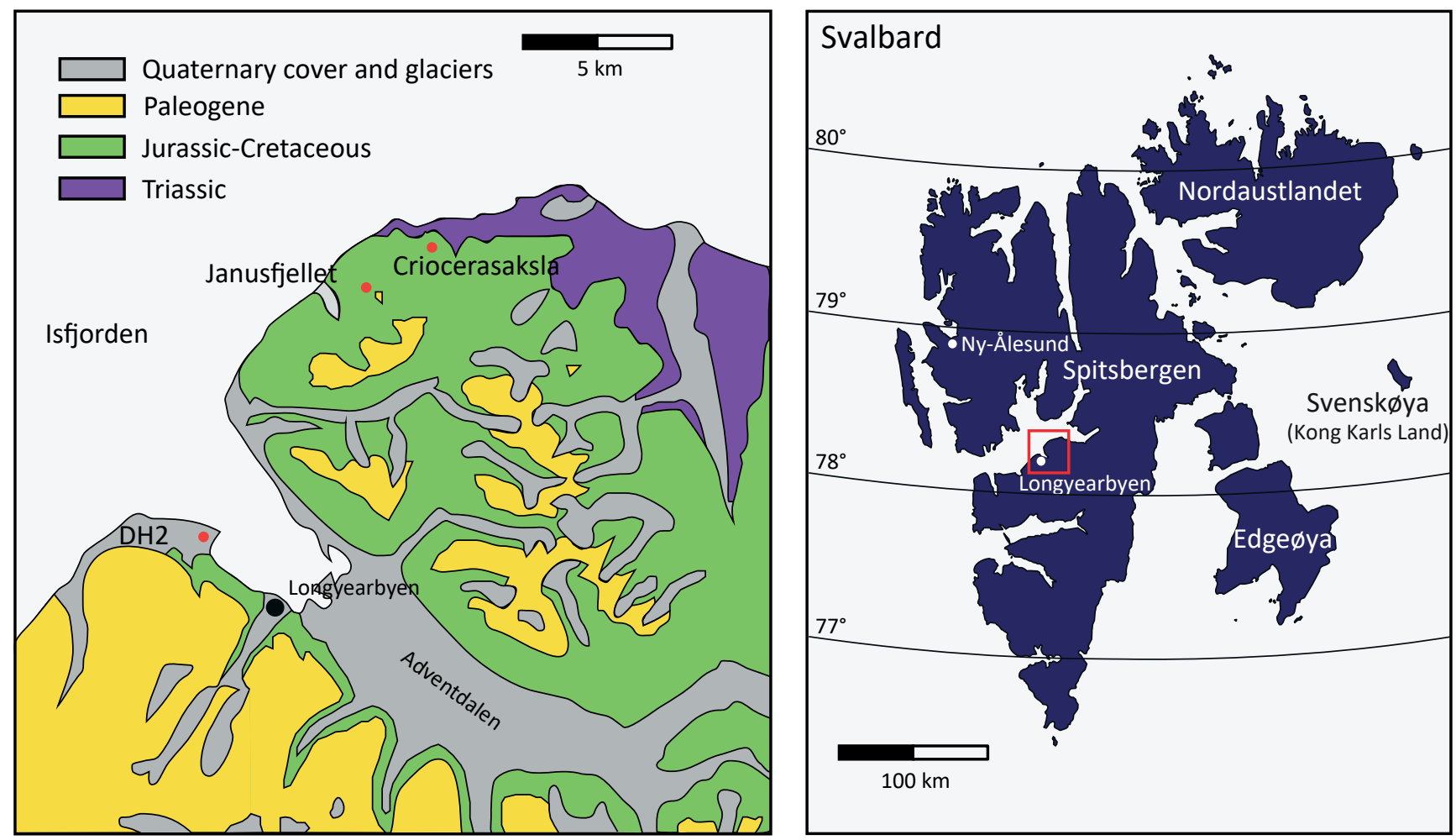

Figure 1. The localities at which isolated elements were discovered in this study in Central Spitsbergen (left) and the location of elements discovered by Nathorst in 1899 on Svenskøya (right).

cored the Agardhfiellet Formation. The drillcore provides a continuous record from the Middle Jurassic (Bathonian) to the lowermost Cretaceous (Ryazanian) and has proven to contain well preserved external moulds of invertebrate fauna (Koevoets et al., 2016).

The genus Leptolepis is somewhat ill-defined as some characteristic features are common among other teleost genera, and many species previously belonging to Leptolepis have been reassigned (e.g., Arratia, 1997, 1999, 2001, 2003, 2013, 2015; Arratia \& Thies, 2001; Arratia \& Hikuroa, 2010). We will compare the presented material to the material of the teleost fish reported from eastern Svalbard (Woodward, 1899), referred to as Leptolepis nathorsti. The definition and characterisation of Leptolepididae follows Arratia (2017), and for Leptolepis Konwert \& Stumpf (2017) are followed without amendments.

\section{Material}

Material used in this study is surface material collected from outcrops of the Agardhfjellet Formation at Janusfiellet and Criocerasaksla (Koevoets et al., 2016) and samples from drillcore DH2 (Adventdalen) which is part of the $\mathrm{CO}_{2}$ Svalbard project (Sand et al., 2014) (Fig. 1). Other material collected from the drillcore significant to this study is a stratigraphic abundance of all fauna, including ammonites, onychites, belemnites, bivalves and in a few cases marine reptile remains. From the outcrop material, eight specimens of teleost remains were collected, and from the drillcore 50 specimens were recognised and logged while 14 samples were removed from the core. The frailty and delicacy of the remains in both the outcrop and the core specimens prohibited preparation in fear of damaging the samples.

The remains consist of disarticulated, scattered and flattened bones. The most common occurrences are isolated dentaries. The stratigraphic distribution spans the complete formation and is associated with onychites (Fig. 2). Although the material does not seem to be associated with a specific lithology, it is somewhat more abundant in black shales of the Lardyfjellet and Slottsmøya members. 


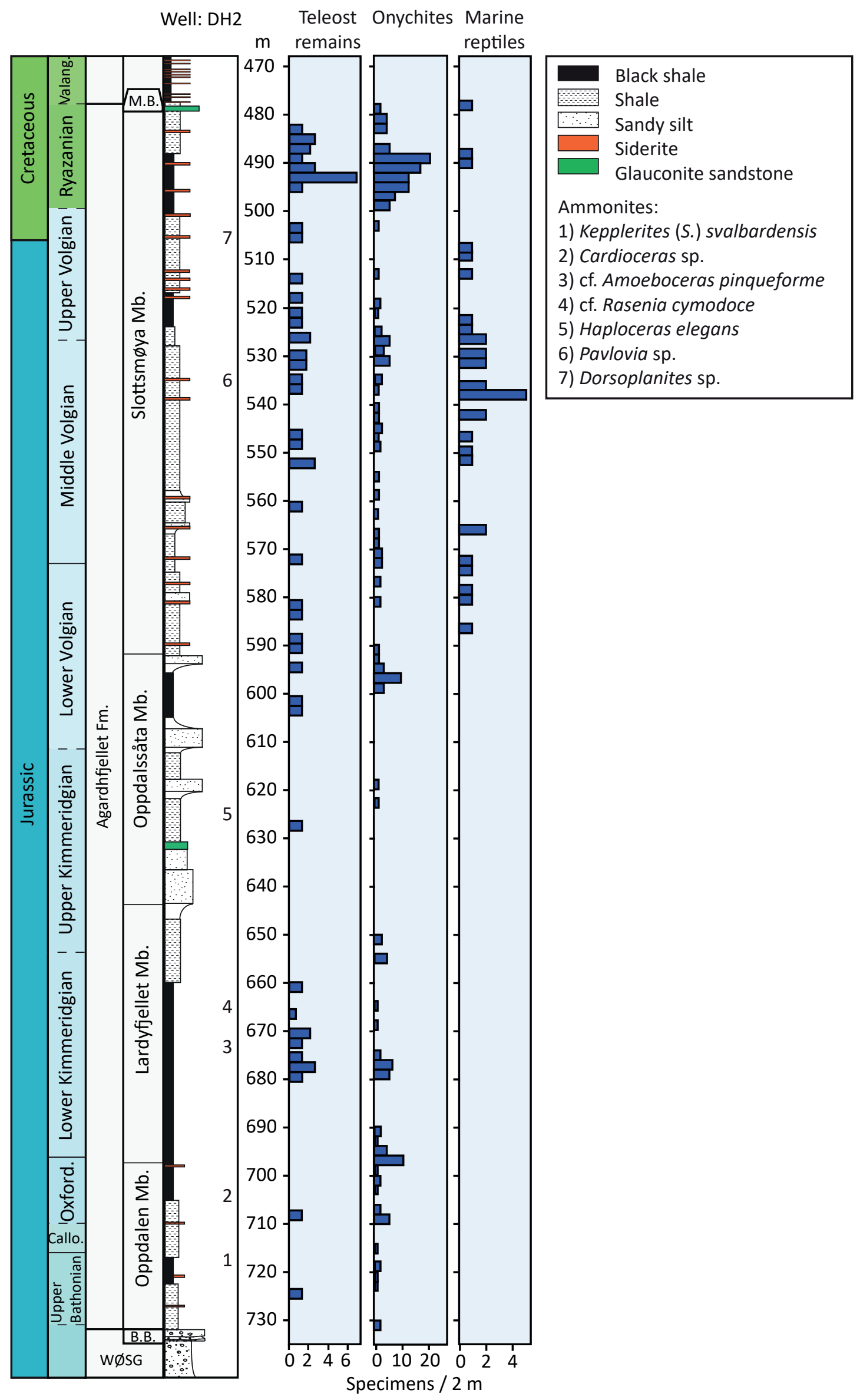

Figure 2. Distribution of fish elements throughout the Agardhfjellet Formation in the DH2 core, central Spitsbergen, Svalbard. Distributions of onychites and marine reptiles are also shown (marine reptiles data from (Delsett et al., 2015). 


\section{Results}

\section{Systematic palaeontology}

\section{Actinopterygii Cope, 1887 \\ Teleostei Müller 1845 \\ Order indet. \\ Leptolepididae Pictet, 1854 \\ Leptolepis Agassiz, 1833}

The characteristics of the genus Leptolepis

To recognise the genus Leptolepis the following characteristics are to be taken into consideration according to Konwert \& Stumpf (2017): one suborbital is present, the accessory suborbital (as described by Nybelin (1974)) is absent (Arratia \& Thies, 2001), the maxilla has a prominent longitudinal ridge on the lateral side, cranial roof elements do not bear ornamentation, the only location fringing fulcra are present is the dorsal lobe of the caudal fin, sclerotics are large and form a ring-like structure, and the postcleithrum is large and elongated. Arratia \& Thies (2001) added the boomerang shape of the preopercle.

The characteristics of $\mathrm{L}$. nathorsti

Nybelin (1974) proposed a preliminary diagnosis: Trapezoidal Opercle. Supraorbital sensory canal in the frontal bone, posteriorly with a postero-laterally directed tubule. The preopercular sensory canal has only six to eight tubules and the limbs of the preopercle are angled at 90 degrees and the cephalic sensory canal is near the arched anterior margin (Nybelin, 1974; Arratia, 1997). Nybelin (1974) later in his description remarks on the presence of a characteristic preopercular process on the hyomandibula, and the probable absence of the small notch in the anterior surface of the dentary to separate it from other species. We will use this character as a feature to assign some of our material loosely to $L$. aff. nathorsti with the taxonomic caveats in mind.

\section{Material description}

Cranial Bones: The frontal bone (Fig. 3) is not completely preserved. The posterior widened end with the sensory canals is preserved, but it seems to be missing most of the narrow anterior end. The supraorbital sensory canal has a slight bend at which issue two postero-medially directed tubules and further backwards a postero-laterally directed tubule. A parietal branch is not present.

Upper Jaw: The maxilla (Figs. 4, 5B, 6B \& 7D) is an elongated convex bone. Teeth or sockets are not visible in any of the specimens. The posteriormost section of the maxilla shows concentric ornamentation. Slightly posterior of the dorsal margin there is an impressed surface, possibly for overlap of supramaxillae. On the lateral side there is a longitudinal ridge visible. The antero-medial end is long and contracted. The maxilla is

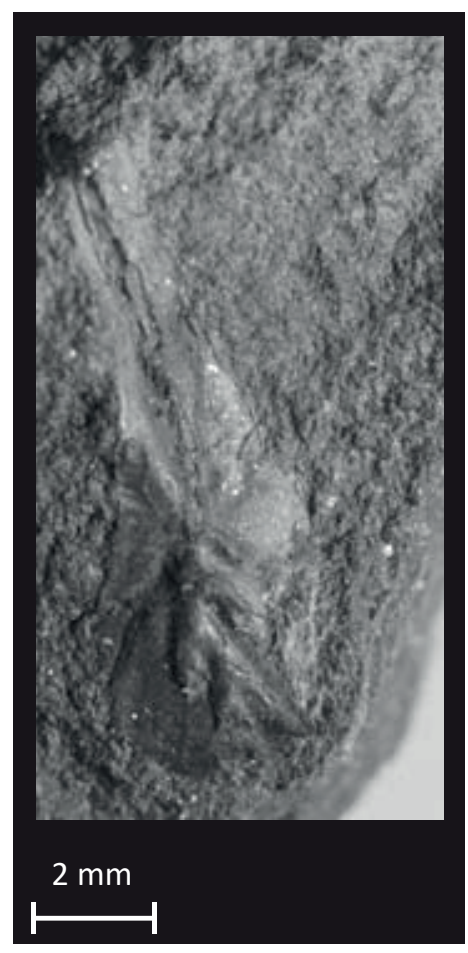

Figure 3. Leptolepis aff. nathorsti. Partial frontal bone, level $98 \mathrm{~m}$ at Janusfjellet, upper Oppdalssåta Member (PMO 228.899b).

abundant throughout the core and in the surface material. Both supramaxillae (Figs. 5B \& 6E) have been found in the material. The anterior supramaxilla (SMX1) (Fig. $5 \mathrm{~B})$ is not completely preserved and the shape is hard to reconstruct. Nybelin (1974) described it to be long and narrow in Leptolepis. The posterior supramaxilla (SMX2) (Fig. 6E) is leaf shaped where the antero-dorsal process tapers into a point, with distinct lateral superficial ornamentation.

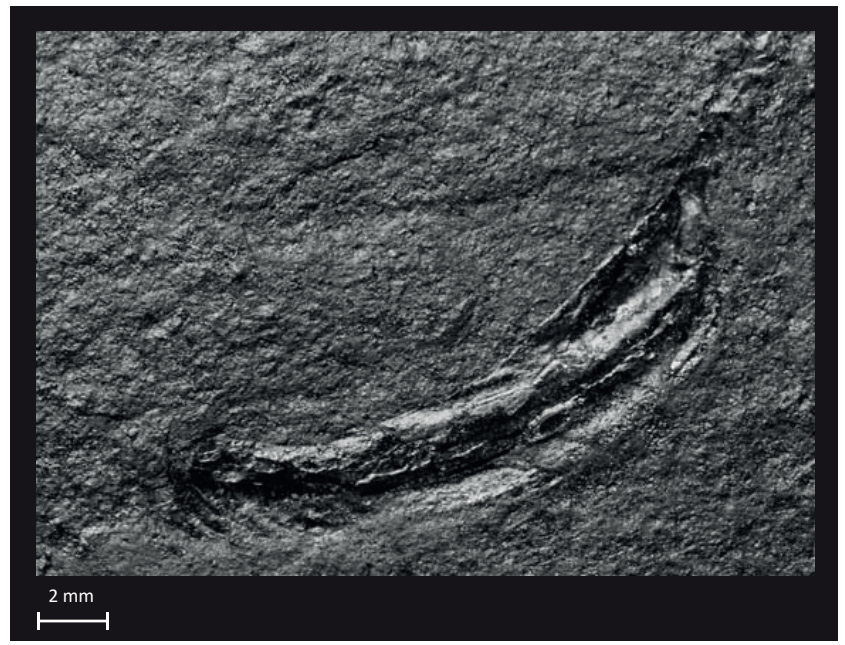

Figure 4. Leptolepis asp. right maxilla, $677.96 \mathrm{~m}$ in DH2, Lardyfjellet Member (PMO 228.870). 


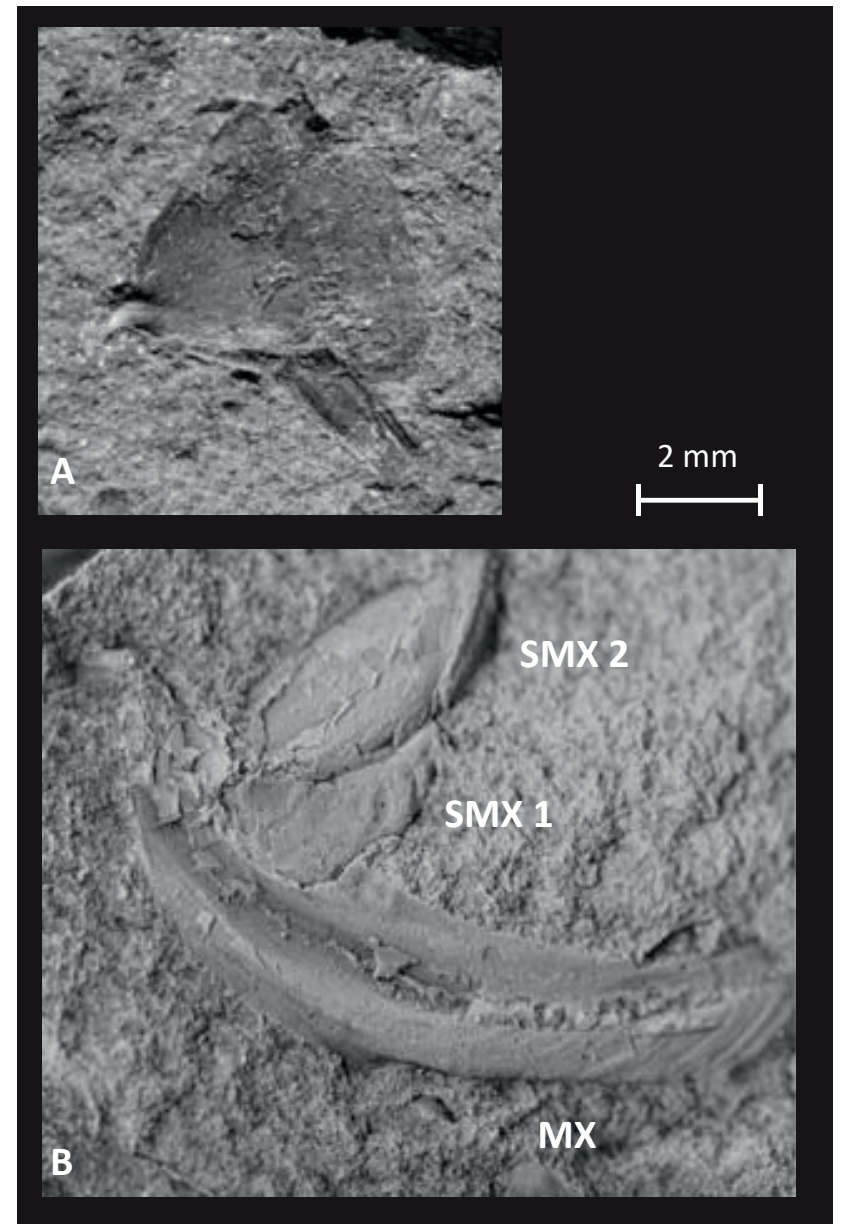

Figure 5. Leptolepis sp. (A) quadrate. (B) Left maxilla, supramaxilla 1 \& 2. From level $98 \mathrm{~m}$ at Janusfjellet, upper Oppdalssåta Member (PMO 228.8966)

Lower Jaw: The dentary (Figs.6C \& 8) is the most common preserved element, possibly because of the thickness of the rostral end, coronoid process and postero-ventral process. The ventral side is slightly convex. The size of the dentigerous area is not known since teeth or sockets are not visible in the specimens observed. There does not seem to be a small leptolepid notch in accordance with the criteria for "leptolepids" (Nybelin, 1974). The angle of the oral margin is at roughly $45^{\circ}$ compared to the anteroposterior axis. The coronoid process is at a $90^{\circ}$ angle and has a thin posterior wing with concentric ornamentation suggesting growth lines. This wing or dentigerous area is not preserved in every specimen. The angular (Fig. 7J) is poorly preserved. The elongated triangular outline is clearly visible and the small posteroventral process is distinguishable.

Circumorbital bones: Two infraorbitals (Fig. 7C, I) are preserved; the sensory canal tubules are next to absent. The sensory canal is still visible. The shape of the infraorbital 3 (Fig. 7I) is squared and there is some light concentric ornamentation visible. The second infraorbital bone is harder to identify, but seems to be infraorbital 4 (Fig. 7C).
Hyoid \& Palatoquadrate arches: The hyomandible (Fig. $7 \mathrm{G}$ ) is preserved only as an impression. The opercular process is wing-like antero-dorsally like the hyomandible figured by Nybelin (1974). There is no sign of a preopercular process, but this could have been broken off after death. The quadrate (Fig. 5B) has a triangular shape and the surface of the bone is smooth. Anteriorly, the condyle is well defined but broken and the base of the postero-ventral quadrato-jugal process present. The length of the process can no longer be derived as it seems to have been broken and partially overlapped by another bone fragment. The anterior ceratohyal (Fig. 9) has an hourglass-shaped main structure. The main recognisable feature of this bone is the delicate thread-like ossification connecting the dorsal tips of its extremities. The thread is not preserved in the specimen, but can be derived from the clear hook-like structure at one side of the extremities where the dorsal tip has a small depressed surface.

Opercular bones: The opercle (Fig. 6A) is badly preserved and possibly damaged, but the trapezoidal shape, dorsally rounded, ventrally sharp-pointed outline is still visible. The concentric ornamentation of the surface is faint. The subopercle (Fig. 7E) has a trapezium shape where the posterior end curves convexly upward and there is a small ascending process at the antero-dorsal corner. The concentric ornamentation is clearly visible. The preopercle (Figs. 6D, 7B \& 9) is sharply bent at its posteroventral angle and the dorsal limb is nearly the same length as the anterior limb. Both taper in to sharp points. The outer face shows the distinctive simple sensory canal, with six ventrally branching tubules.

Vertebral column: There are numerous vertebral centra present (Figs.6F, G \& 7F,H). They are flattened, thin-walled, somewhat hourglass-shaped bones. Several have smooth surfaces and others show ring-like structures, indicative of chordacentra. Unfortunately, due to poor preservation, articulacy surfaces of the arches or parapophyses were not observed. Internal moulds of the vertebrae show the diameter for the notochord was unconstricting.

Pectoral girdle: The cleithrum (Figs. 7A \& 11) has an 's'-shaped anterior edge and bends sharply at its posteroventral edge. The dorsal limb is stout and short. The ventral limb is longer and more slender.

\section{Discussion}

The long antero-medial end of the maxilla (PMO 228.895 and PMO 228.870) places our specimens in the "leptolepid" group according to Nybelin (1974). More recent studies have shown that the length of the anterior end of the maxilla is variable within leptolepid species (Arratia, 2017; Konwert \& Stumpf, 2017). A long process can also be found in the Late Jurassic genera Leptolepides 


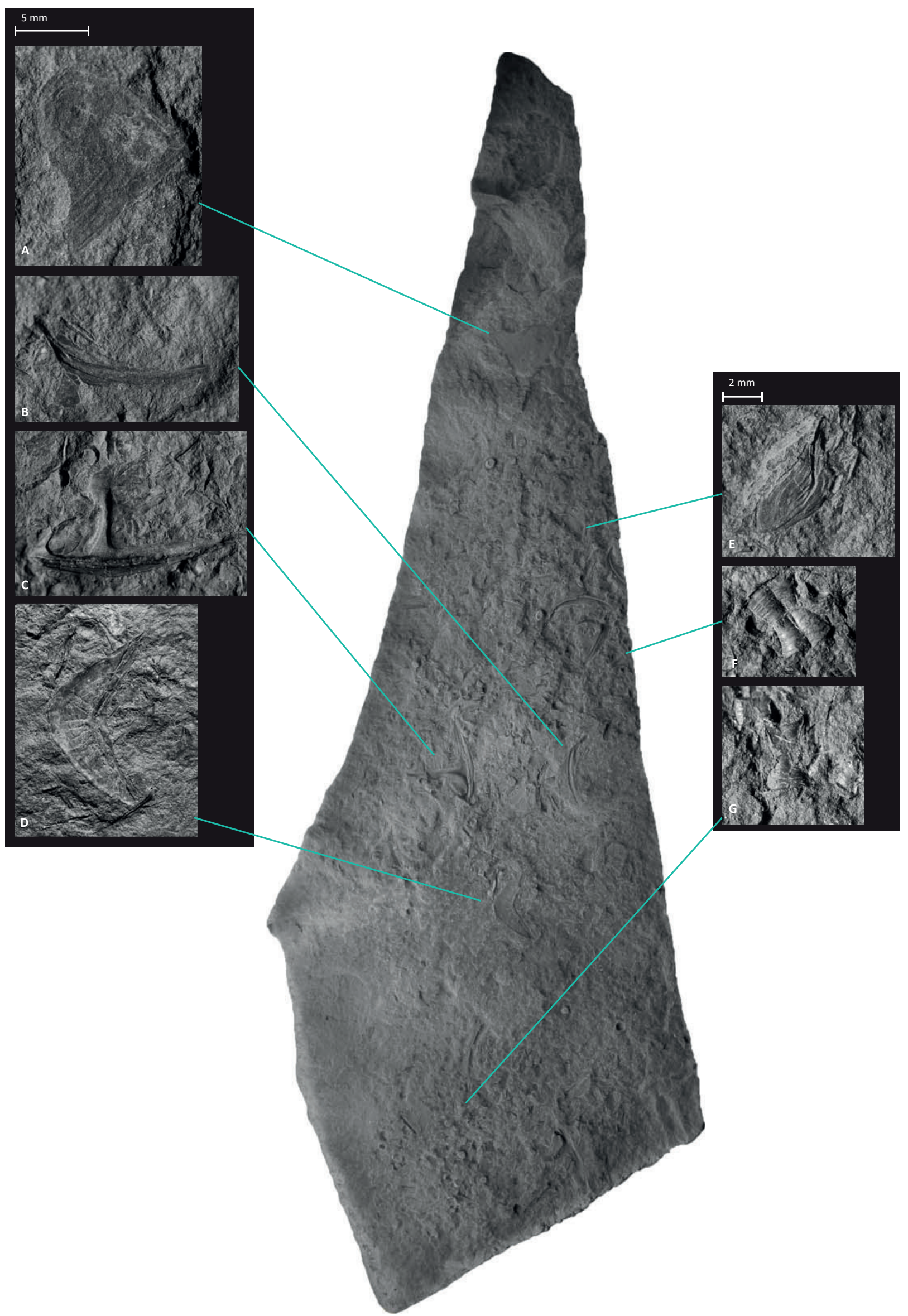

Figure 6. The specimen PMO 228.893, level $38 \mathrm{~m}$ at Criocerasaksla, Upper Lardyfjellet Member. The slab contains several disarticulated elements belonging to L. aff. nathorsti. Highlighted are (A) opercle, (B) maxilla, (C) dentary, (D) preopercle, (E) supramaxilla 2 and (F \& G) vertebral centra. 


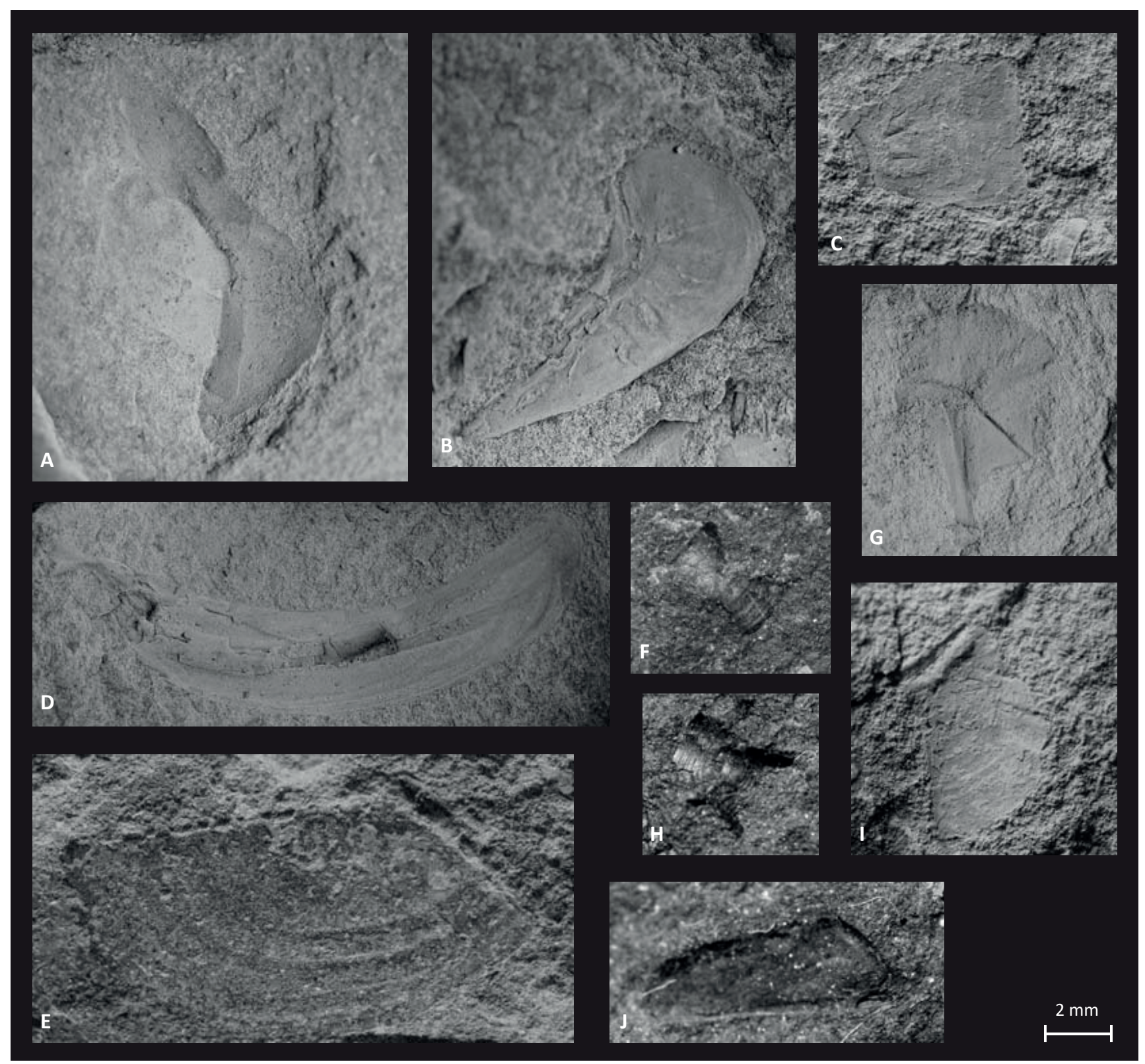

Figure 7. APMO 228.895 found at level $98 \mathrm{~m}$ at Janusfjellet, upper Oppdalssåta Member, contains the following isolated elements assigned to Leptolepis sp. (A) cleithrum, (B) partial preopercle, (C) Infraorbital 4, (D) partial maxilla, (E) subopercle. The preopercle (B) possibly belongs to L aff. nathorsti.

and Orthogonikleithrus and other Late Jurassic teleosts (Arratia, 2017; Konwert \& Stumpf, 2017). The genus Leptolepis has been the subject of revisions and is probably polyphyletic (Arratia, 1997, 2003). Some characteristics of Leptolepis are based on presence, absence or location of cranial/skeletal elements, useless for the disarticulated, isolated remains presented here, or on cranial elements not encountered. However, the remains collected in this study show strong resemblance to other species referred to the genus Leptolepis (Delsate \& Thuy, 2005). In particular, the boomerang shape of the preopercle, its well defined limbs, and the prominent longitudinal ridge on the lateral side of the maxilla do compare to those found in Leptolepis (Arratia \& Thies, 2001; Konwert \& Stumpf, 2017). Woodward (1899) did not establish a holotype of the species L. nathorsti, but Nybelin (1974) felt that the preopercle could be used as a lectotype. The frontal bone (Fig. 3), preopercle (Fig. 10) and hyomandilbe (Fig. 7G) all show characteristic features ascribed to $L$. nathorsti by Nybelin (1974). We therefore refer both the preopercle and the hyomandible to Leptolepis aff. nathorsti together with the associated bones on the same slab (PMO 228.893) from $38 \mathrm{~m}$ in the Criocerasaksla section, upper Lardyfjellet Member (Lower Kimmeridgian) (Fig. 6) (opercle, vertebra, supramaxilla 2, preopercle, dentary, maxilla) (Koevoets et al., 2016), and slabs found at 98 $\mathrm{m}$ in the Janusfjellet section, in the upper part of the Oppdalssåta Member (Upper Kimmeridgian), together with the bones shown in Figure 7 (maxilla, subopercle, cleithrum, frontal bone, supramaxilla 1 , infraorbital 4 , 


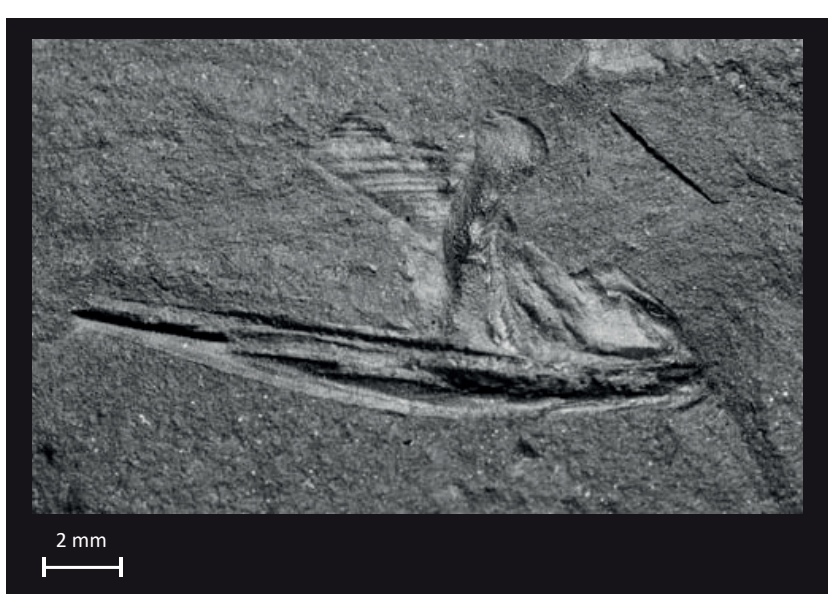

Figure 8. Right dentary, level $536.45 \mathrm{~m}$ in DH2 core, Slottsmøya Member (PMO 228.781) assigned to Leptolepis sp.

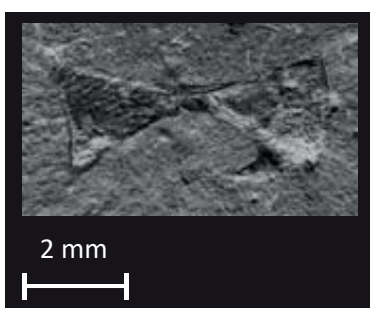

Figure 9. Isolated partial anterior ceratohyal, level $553.40 \mathrm{~m}$ in $\mathrm{DH} 2$ core, Slottsmøya Member (PMO 228.802) assigned to Leptolepis sp.

Infraorbital 3, vertebra, quadrate and anterior ceratohyal). A tentative reconstruction of the skull (Fig. 12) based on the cranial material of this study was possible following guidelines from Nybelin (1974).

Other teleost elements of similar size and appearance as in the associations mentioned were found almost throughout the formation (Fig. 2), but since they were isolated and not associated with the diagnostic elements for L. nathorsti, they cannot be assigned to a species.

"Leptolepids" are distributed throughout the entire Agardhfjellet Formation (Fig 2). Considering the time span of the formation, it is highly unlikely that all specimens belong to $L$. aff. nathorsti. The diagnostic preopercula have so far been found only in the upper part of the Lardyfjellet Member at Criocerasaksla and in the upper part of the Oppdalssåta Member at Janusfjellet. This corresponds to Early and Late Kimmeridgian in age, respectively, which is considerably younger than previously reported for L. nathorsti (Woodward, 1899; Nybelin, 1974; Ginsburg \& Janvier, 1974).

L. nathorsti was described to be of Early Jurassic age by Woodward (1899). His conclusion was based on the resemblance to a teleost group characteristic of the

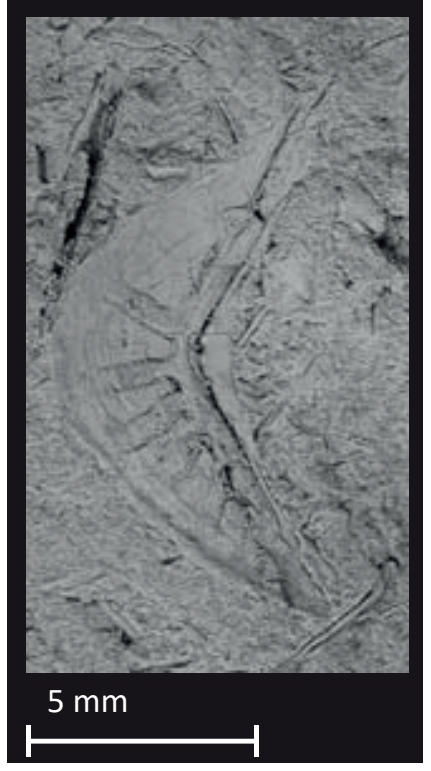

Figure 10. Detailed high-contrast image of preopercle (PMO 228.893) belonging to L. aff. nathorsti.

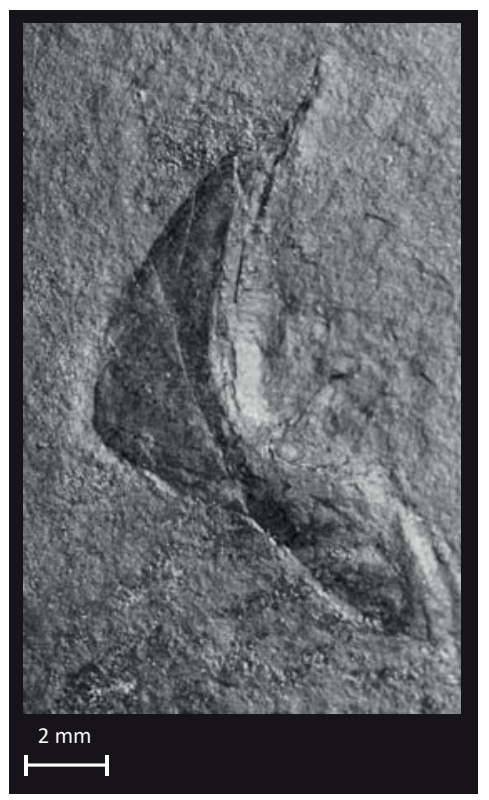

Figure 11. Left cleithrum belonging to Leptolepis sp. Found at level $676.10 \mathrm{~m}$ in DH2, Lardyfjellet Member (PMO 228.867).

Toarcian (Upper Lias, Woodward (1899)) to Bathonian of mainland Europe. The material Woodward described was retrieved from Svenskøya and Kong Karls Land. The latter location was further specified by Nathorst (1901) as the southern slopes of Tordenskioldberget. Judging from the location, strata description as Aucella-shales by Nathorst (1901), collector of the material, and the detailed study ascribing an Early Oxfordian to Kimmeridgian age to these sediments by Smith et al. (1976), it must be concluded that the material is more likely Kimmeridgian in age. 


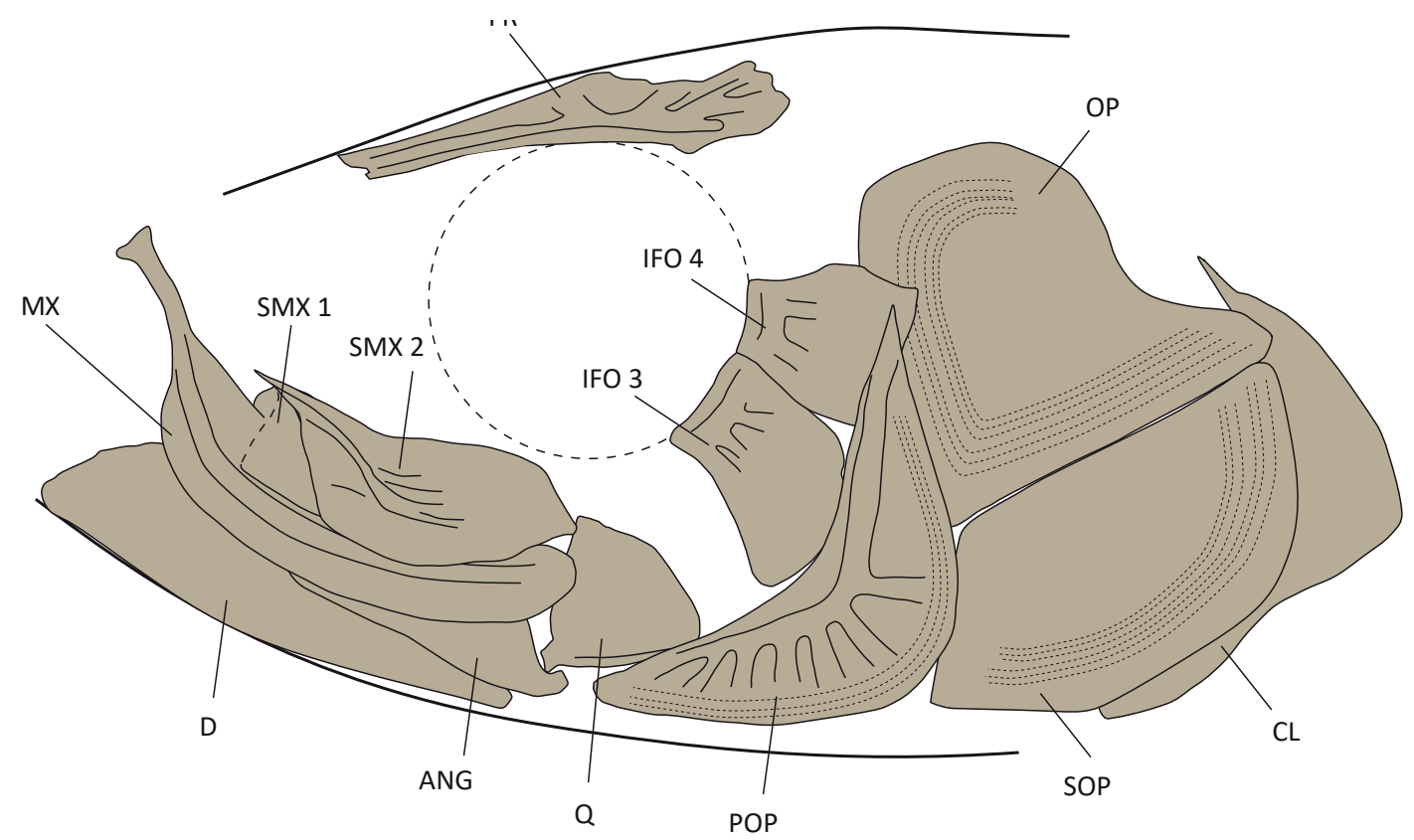

Figure 12. Tentative reconstruction of Leptolepis aff. nathorsti based on associated cranial material from PMO 228.893 (38 $\mathrm{m}$ at Janusfjellet, Middle Volgian). FR - Frontal bone, MX - Maxilla, SMX 1 - Supramaxilla 1, SMX 2 - Supramaxilla 2, D - Dentary, ANG - Angular, Q Quadrate, IFO 3 - Infraorbital 3, IFO 4 - Infraorbital 4, POP - Preopercle, OP - Opercle, SOP - Subopercle \& CL - Cleithrum.

Ginsburg \& Janvier (1974) mentioned encountering remains of $L$. nathorsti from the Toarcian at Lardyfjellet, East Spitsbergen. From the original report (Woodward, 1899) it is impossible to determine if the assumption of a Toarcian age is correct, since the mentioned characteristic ammonites are not named or pictured. The sediments are described as fine silts overlain by bituminous shales with thin carbonate beds, containing belemnites and ammonites (Woodward, 1899). This description of the strata bears more resemblance to the lower part of the Agardhfjellet Formation, namely the Oppdalen and Lardyfjellet members (Dypvik, 1984; Mørk et al., 1999; Dypvik et al., 2002; Koevoets et al., 2016).

Nybelin (1974) studied L. nathorsti more extensively than Woodward (1899) as part of a revision on "leptolepid" fishes. More material was obtained from a French expedition in 1969, which he described along with the existing material collected by Woodward. The French material was found at Deltaneset, Central Spitsbergen. Nybelin (1974) also based the age on the presence of Toarcian ammonites which in this article also are not depicted or described, making it difficult to verify. There is mention of the material described by Nybelin (1974) being associated with lower Lias "Tricleidus svalbardensis" (Persson, 1962), a species of plesiosaur recently redescribed as Colymbosaurus svalbardensis from the Slottsmøya Member (Volgian) by Knutsen et al. (2012a) and recent work by Roberts et al. (2017), after new specimens and information on the actual locality were discovered
Later studies have shown that the only substantial Toarcian deposits in the Svalbard archipelago are found in Kong Karls Land, and these deposits consist mainly of sandstones (Harland et al., 1997; Mørk et al., 1999). This does not resemble the description of the black paper shales in which L. nathorsti was found by Nathorst (1901), Ginsburg \& Janvier (1974) or Nybelin (1974). The only recent find of Toarcian ammonites in central and eastern Spitsbergen is in the Brentskardhaugen Bed (Bäckström \& Nagy, 1985), which is a reworked conglomerate deposit marking the end of a hiatus (Harland et al., 1997; Mørk et al., 1999). Black paper shales are characteristic for the Oppdalen and Lardyfjellet members of the Agardhfjellet Formation (Dypvik, 1984; Mørk et al., 1999; Koevoets et al., 2016).

Comparing the finds in this study, which are Kimmeridgian to Volgian in age, and the recent research on stratigraphy in Kong Karls Land and Spitsbergen, it is more likely that the material described by Woodward (1899) was found in the paper shales of the Kimmeridgian Dunerfjellet Member (Smith et al., 1976; Dypvik, 1984; Mørk et al., 1999; Koevoets et al., 2016). This is in compliance with the characteristic cranial elements found in this study, associated with ammonites like the Lower Kimmeridgian cf., Amoeboceras pingueforme (Wierzbowski, 1989; Rogov, 2014; Koevoets et al., 2016) and the Upper Kimmeridgian Haplocardioceras elegans and Zenostephanus sp. Other teleost jaw elements are distributed throughout the formation and are also found at levels associated with the Bathonian Kepplerites (Seymourites) svalbardensis (Kopik \& Wierzbowski, 1988; Koevoets et al., 2016), Oxfordian 
Cardioceras sp. (Koevoets et al., 2016) and Middle Volgian Dorsoplanites sp. (Nagy \& Basov, 1998; Rogov, 2010; Koevoets et al., 2016). These bones resemble the dentary and maxilla of $L$. aff. nathorsti, but the features are too similar to the jaw elements of other Leptolepis species and other teleosts to assign to $L$. aff. nathorsti beyond any reasonable doubt.

The teleost remains follow the occurrences of onychites closely (Fig. 2), suggesting they preferred similar habitats or preservation environment. Their occurrences extend into the Slottsmøya Member, coinciding with the numerous ichthyosaur and plesiosaur finds in the Jurassic of Central Spitsbergen (Hurum et al., 2012; Delsett et al., 2015). Several ichthyosaurs from the Jurassic around the world have been found with stomach contents. Most contain a mixture of cephalopod hooklets (Hammer et al., 2013) and teleost fish remains (Pollard, 1968; Keller, 1976; Bürgin, 2000), and this is also true for the coprolites where fish remains are more common (Pollard, 1968). A few larger vertebrates like ichthyosaurs, turtles and birds are identified in singular finds (Kear et al., 2003). The stomach contents of Jurassic long-necked plesiosaurs are similar to the ichthyosaurs, with cephalopod hooklets (Martill, 1993) and teleosts (Storrs, 1995). The Late Jurassic ichthyosaurs and long-necked plesiosaurs found in the Slottsmøya Member are mostly found without stomach contents, but it is likely that both groups fed on a mixture of cephalopods and teleosts.

\section{Conclusions}

Comparing the finds from the Lardyfjellet Member and the Oppdalssåta Member presented here to the material of L. nathorsti presented by Woodward (1899) and Nybelin (1974), with special focus on the preopercle which appears identical, there is little doubt that some of these remains belong to the same species. The stratigraphic location of the characteristic preopercles places $L$. nathorsti in the Kimmeridgian, not the Toarcian as previously assumed. Non-diagnostic elements of teleosts of similar size in the Agardhfjellet Formation suggest the presence of at least one species of "leptolepid" in the Volgian of Spitsbergen.

The presence of cephalopod hooklets in the Agardhfjellet Formation was already confirmed by Hammer et al. (2013), allowing for an educated guess that the larger Arctic marine reptiles fed upon belemnoids. Now, with the confirmed presence of teleosts in the Middle to Upper Jurassic of Spitsbergen, the spectrum of possible prey can be increased with more certainty.
Acknowledgements. This paper is a contribution from the Spitsbergen Jurassic Research Group (SJRG). The authors wish to acknowledge Matt Friedman for his help in the initial stages of identification and advice in writing the article, Gloria Arratia and Adriana López-Arbarello for their help, extensive knowledge on teleosts, reviews on identifying the specimens and valuable improvements on the content and depth of this manuscript. We thank our financial supporters for making the fieldwork possible, UNIS and the $\mathrm{CO}_{2}$ Svalbard Project for making the drillcores available to us.

\section{References}

Agassiz, L. 1833: Recherches sur les poissons fossiles: Tome 2. Petitpierre. Arratia, G. 1997: Basal teleosts and teleostean phylogeny. Palaeo Ichthyologica 7, 1-168.

Arratia, G. 1999: The monophyly of Teleostei and stem-group teleosts. Mesozoic fishes 2, 265-334.

Arratia, G. 2001: The sister-group of Teleostei: consensus and disagreements. Journal of Vertebrate Paleontology 21, 767-773. https://doi.org/10.1671/0272-4634(2001)021[0767:TSGOTC]2.0.CO;2.

Arratia, G. 2003: Leptolepis, Paraleptolepis (Teleostei) and a New Fish Name. Fossil Record 6, 157-159. https://doi.org/10.5194/fr-6-157-2003.

Arratia, G. 2013: Morphology, taxonomy, and phylogeny of Triassic pholidophorid fishes (Actinopterygii, Teleostei). Journal of Vertebrate Paleontology 33, 1-138. https://doi.org/10.1080/027246 34.2013.835642.

Arratia, G. 2015: Complexities of early Teleostei and the evolution of particular morphological structures through time. Copeia 103, 9991025. https://doi.org/10.1643/CG-14-184.

Arratia,G.2017:New Triassicteleosts (Actinopterygii,Teleosteomorpha) from northern Italy and their phylogenetic relationships among the most basal teleosts. Journal of Vertebrate Paleontology 37, e1312690. https://doi.org/10.1080/02724634.2017.1312690.

Arratia, G. \& Thies, D. 2001: A new teleost (Osteichthyes, Actinopterygii) from the Early Jurassic Posidonia shale of northern Germany. Fossil Record 4, 167-187. https://doi.org/10.5194/fr-4-167-2001.

Arratia, G. \& Hikuroa, D.C. 2010: Jurassic fishes from the Latady Group, Antarctic Peninsula, and the oldest teleosts from Antarctica. Journal of Vertebrate Paleontology 30, 1331-1342. https://doi.org/10.1080/02724634.2010.501448.

Braathen, A., Bælum, K., Christiansen, H.H., Dahl, T., Eiken, O., Elvebakk, H., Hansen, F., Hanssen, T.H., Jochmann, M., Johansen, T.A., Johnsen, H., Larsen, L., Lie, T., Mertes, J., Mørk, A., Mørk, M.B., Nemec, W., Olaussen, S., Oye, V., Rød, K., Titlestad, G.O., Tveranger, J. \& Vagle, K. 2012: The Longyearbyen $\mathrm{CO}_{2}$ Lab of Svalbard, Norway-initial assessment of the geological conditions for $\mathrm{CO}_{2}$ sequestration. Norwegian Journal of Geology 92, 353-376.

Bürgin, T. 2000: Euthynotus cf. incognitus (Actinopterygii, Pachycormidae) als Mageninhalt eines Fischsauriers aus dem Posidonienschiefer Süddeutschlands (Unerer Juras, Lias epsilon). Eclogae Geologicae Helvetiae 93, 491-496.

Bäckström, S.A. \& Nagy, J. 1985: Depositional history and fauna of a Jurassic phosphorite conglomerate (the Brentskardhaugen Bed) in Spitsbergen. Norsk Polarinstitutt Skrifter 183, 1-61.

Cope, E.D. 1887: Geology and palaeontology. The American Naturalist 21, 1014-1019. https://doi.org/10.1086/274597.

Delsate, D. \& Thuy, B. 2005: Biostratigraphie et paléontologie de l'Hettangien en Belgique et au Grand-Duché de Luxembourg. Geological Survey of Belgium 51,1-93.

Delsett, L.L., Novis, L.K., Roberts, A.J., Koevoets, M.J., Hammer, Ø., Druckenmiller, P.S. \& Hurum, J.H. 2015: The Slottsmøya marine reptile Lagerstätte: depositional environments, taphonomy and diagenesis. Geological Society of London, Special Publications 434, 165-188. https://doi.org/10.1144/SP434.2. 
Druckenmiller, P.S., Hurum, J.H., Knutsen, E.M. \& Nakrem, H.A. 2012: Two new ophthalmosaurids (Reptilia: Ichthyosauria) from the Agardhfjellet Formation (Upper Jurassic: Volgian/Tithonian), Svalbard, Norway. Norwegian Journal of Geology 92, 311-339.

Dypvik, H. 1984: Jurassic and Cretaceous black shales of the Janusfjellet Formation, Svalbard, Norway. Sedimentary Geology 41, 235-248. https://doi.org/10.1016/0037-0738(84)90064-2.

Dypvik, H., Håkansson, E. \& Heinberg, C. 2002: Jurassic and Cretaceous palaeogeography and stratigraphic comparisons in the North Greenland-Svalbard region. Polar Research 21, 91-108. https://doi.org/10.3402/polar.v21i1.6476.

Ginsburg, L. \& Janvier, P. 1974: Un nouveau gisement à Plésiosaures dans le Jurassique du Spitsbergen (Archipel du Svalbard). Årbok Norsk Polarinstitutt 1974, 262-265.

Hammer, Ø., Hryniewicz, K., Hurum, J.H., Høyberget, M., Knutsen, E.M. \& Nakrem, H.A. 2013: Large onychites (cephalopod hooks) from the Upper Jurassic of the Boreal Realm. Acta Palaeontologica Polonica 58, 827-835.

Harland, W.B., Anderson, L.M., Manasrah, D., Butterfield, N.J., Challinor, A., Doubleday, P. A., Dowdeswell, E.K., Dowdeswell, J.A., Geddes, I., Kelly, S.R.A., Lesk, E.L., Spencer, A. M. \& Stephens, C.F. 1997: The geology of Svalbard. Geological Society Memoir 17, 521 pp.

Hurum, J.H., Nakrem, H.A., Hammer, Ø., Knutsen, E.M., Druckenmiller, P.S., Hryniewicz, K. \& Novis, L.K. 2012: An Arctic Lagerstätte the Slottsmøya Member of the Agardhfjellet Formation (Upper Jurassic-Lower Cretaceous) of Spitsbergen. Norwegian Journal of Geology 92, 55-64.

Kear, B.P., Boles, W.E. \& Smith, E.T. 2003: Unusual gut contents in a Cretaceous ichthyosaur. Proceedings of the Royal Society of London B: Biological Sciences 270, S206-S208. https://doi.org/10.1098/rsbl.2003.0050.

Keller, T. 1976: Magen-und Darminhalte von Ichthyosauriern des süddeutschen Posidonienschiefers. Neues Jahrbuch für Geologie und Paläontologie, Monatshefte 1976, 266-283.

Knutsen, E.M., Druckenmiller, P.S. \& Hurum, J.H. 2012a: Redescription and taxonomic clarification of'Tricleidus' svalbardensis based on new material from the Agardhfjellet Formation (Middle Volgian). Norwegian Journal of Geology 92, 175-186.

Knutsen, E.M., Druckenmiller, P.S. \& Hurum, J.H. 2012b: Two new species of long-necked plesiosaurians (Reptilia: Sauropterygia) from the Upper Jurassic (Middle Volgian) Agardhfjellet Formation of central Spitsbergen. Norwegian Journal of Geology 92, 187-212.

Koevoets, M.J., Abay, T.B., Hammer, Ø. \& Olaussen, S. 2016: Highresolution organic carbon-isotope stratigraphy of the Middle Jurassic-Lower Cretaceous Agardhfjellet Formation of central Spitsbergen, Svalbard. Palaeogeography, Palaeoclimatology, Palaeoecology 449, 266-274. https://doi.org/10.1016/j.palaeo.2016.02.029.

Konwert, M. \& Stumpf, S. 2017: Exceptionally preserved Leptolepidae (Actinopterygii, Teleostei) from the late Early Jurassic FossilLagerstätten of Grimmen and Dobbertin (Mecklenburg-Western Pomerania, Germany). Zootaxa 4243, 249-296. https://doi.org/10.11646/zootaxa.4243.2.2.

Kopik, J. \& Wierzbowski, A. 1988: Ammonites and stratigraphy of the Bathonian and Callovian at Janusfjellet and Wimanfjellet, Sassenfjorden, Spitsbergen, Norway. Acta Palaeontologica Polonica $33,145-168$.

Martill, D.M. 1993: Soupy substrates: amediumforthe exceptional preservation of ichthyosaurs of the Posidonia Shale (Lower Jurassic) of Germany. Kaupia-Darm-städter Beiträge zur Naturgeschichte 2, 11-91.

Müller, J. 1845: Über den Bau und die Grenzen der Ganoiden und über das natürliche System der Fische. Bericht der Akademie der Wissenschaften Berlin 1844, 416-422.
Mørk, A., Dallmann, W.K., Dypvik, H., Johannessen, E.P., Larssen, G.B., Nagy, J., Nøttevedt, A., Olaussen, S., Pčelina, T.M. \& Worsley, D. 1999: Mesozoic lithostratigraphy. In Dallmann, W.K. (ed.): Lithostratigraphic Lexicon of Svalbard. Review and Recommendations for Nomenclature Use. Upper Palaeozoic to Quaternary Bedrock, Norsk Polarinstitutt Tromsø, Norway, pp. 127-214.

Nagy, J. \& Basov, V.A. 1998: Revised foraminiferal taxa and biostratigraphy of Bathonian to Ryazanian deposits in Spitsbergen. Micropaleontology 44, 217-255. https://doi.org/10.2307/1486047.

Nathorst, A.G. 1901: Bidrag till Kung Karls lands geologi. Geologiska Föreningen i Stockholm Förhandlingar 23, 341-378.

Nybelin, O. 1974: A Revision of the Leptolepid Fishes. Acta Regia Societatis Scientiarum et Litterarum Gothoburgensis Zoologica 9, $1-202$.

Persson, P.O. 1962: Plesiosaurians from Spitsbergen. Årbok Norsk Polarinstitutt 1962, 62-68.

Pictet, F.J. 1854: Traité de paléontologie ou histoire naturelle des animaux fossiles. Baillière, Paris, $674 \mathrm{pp}$.

Pollard, J.E. 1968: The gastric contents of an ichthyosaur from the Lower Lias of Lyme Regis, Dorset. Palaeontology 11, 376-388.

Roberts, A.J., Druckenmiller, P.S., Sætre, G.P. \& Hurum, J.H. 2014: A new Upper Jurassic ophthalmosaurid ichthyosaur from the Slottsmøya Member, Agardhfjellet Formation of central Spitsbergen. Public Library of Science ONE 9.

Roberts, A.J., Druckenmiller, P.S., Delsett, L.L. \& Hurum, J.H. 2017: Osteology and relationships of Colymbosaurus Seeley, 1874, based on new material of C. svalbardensis from the Slottsmøya Member, Agardhfjellet Formation of central Spitsbergen. Journal of Vertebrate Paleontology 37, e1278381. https://doi.org/10.1080/02724634.2017.1278381.

Rogov, M.A. 2010: New data on ammonites and stratigraphy of the Volgian stage in Spitzbergen. Stratigraphy and Geological Correlation $18,505-531$.

Rogov, M.A. 2014: An infrazonal ammonite biostratigraphy for the Kimmeridgian of Spitsbergen. Norwegian Petroleum Directorate Bulletin 11, 153-165.

Sand, G., Braathen, A. \& Olaussen, S. 2014: Longyearbyen $\mathrm{CO}_{2} \mathrm{Lab}$ tales of research and education. Norwegian Journal of Geology 94, $77-82$.

Smith, D., Harland, W., Hughes, N. \& Pickton, C. 1976: The geology of Kong Karls Land, Svalbard. Geological Magazine 113, 193-232. https://doi.org/10.1017/S001675680004320X.

Storrs, G. 1995: A juvenile specimen of? Plesiosaurus sp. from the Lias (Lower Jurassic, Pliensbachian) near Charmouth, Dorset, England. Proceedings of the Dorset Natural History and Archaeological Society $116,70-76$

Wierzbowski, A. 1989: Ammonites and stratigraphy of the Kimmeridgian at Wimanfjellet, Sassenfjorden, Spitsbergen. Acta Palaeontologica Polonica 34, 355-378.

Woodward, A.S. 1899: Notes on fossil fish-remains collected in Spits bergen by the Swedish Arctic Expedition, 1898. Kungliga Svenska Vetenskaps Aakademiens Handlingar B 25. 